\title{
RAYKHANOV U.A. THE PLACE OF INNOVATIVE DEVELOPMENTS AND PRIVATE ENTREPRENEURSHIP IN THE EXPANSION OF THE MIDDLE CLASS IN UZBEKISTAN
}

\author{
RAYKHANOV ULUGMUROD ALIEVICH \\ Senior teacher of the \\ Faculty of Economics, \\ National University of Uzbekistan
}

The article considers the significance of the expansion of the middle class, its current state, development trends. Also, there isdescribed the scientific and theoretical issuesof innovative developments and private entrepreneurship in the expansion of the middle class.

Key words: active entrepreneurship, reform path, middle class, innovative product, innovative approach.

In the transition to a market economy, all countries attach great importance to the formation and expansion of the middle class.Because the deepening of market reforms and social stability in the society are closely related to the fact that this class has a high share of the population.

In Uzbekistan, the share of the middle class in the structure of the population has peculiarities, where private entrepreneurship plays a leading role. In this regard, Shavkat Mirziyoev, President of Uzbekistan, commented: "In this regard, the concept of active entrepreneurship should be briefly mentioned. An effective entrepreneurship is an innovational business that is based on modern approaches, advanced technology and management methods. When we speak about an active businessman, we understand entrepreneurs who are able to produce competitive products and, most importantly, create new jobs and not only feed themselves and their families, but also benefit the entire society. It is our first priority in expanding the ranks of such entrepreneurs, creating appropriate conditions for bringing them into our country, introducing advanced technology, science-based equipment and technics. We need to provide them with the opportunity to gain experience and mutually beneficial cooperation with leading foreign companies and organizations" ${ }^{1 " .}$

The relevance of this issue can also be explained by the reforms undertaken in the country. For this purpose, the Resolution of the President of the Republic of Uzbekistan "On the Establishment of the State Fund for Supporting the Development of Entrepreneurship" was adopted on August 17, 2017 and the Ministry of innovative development of the Republic of Uzbekistan was established on November 30, 2016 by the Resolution No. PQ-3416 ${ }^{2}$. The President has declared 2018 the "Year of Active Entrepreneurship, Support for Innovation Ideas

\footnotetext{
${ }^{1}$ Address of the President of the Republic of Uzbekistan Shavkat Mirziyoev to Supreme Assembly.http://uza.uz/oz/ documents/zbekiston-respublikasi-prezidenti-shavkat-mirziyeevning-oliy-22-12-2017

${ }^{2}$ http://lex.uz/Pages/GetPage.aspx?lact id $=3431440$
} 
and Technologies"', as well as the Strategic Action Plan for the Development of the Republic of Uzbekistan in five priority areas of 2017-2021: "The Year of Active Entrepreneurship, Support for Innovation Ideas and Technologies" the State Program on Implementation was developed ${ }^{4}$.

The world practice shows that at present, the reform of the development of the middle class and its share enhancement is both practical and theoretical. This historic way of forming the middle class as a result of the transformation of private property into forced state property during the Soviet Union was denied.

At present, the state plays an important role in the expansion and development of the middle class by means of reforms in the modernization of the economy. As a result of the reform, shaping, expanding and enlarging the middle class, a rapidly growing world-class population's quantity and income are now being observed.

Research has shown that the problem of hunger is diminishing as the financial support of the world's population is increasing. The poverty line in the whole world is to half, the size of $\$ 1.9$ billion in 1990 and 836 million people in 2015 were decreased. The share of non-food population in the developing world decreased from $23.3 \%$ in $1990-1992$ to $12.9 \%$ in 2014 .According to the UN estimates, for the period 1991-2015, the costs of living standards of the "middleaged" population have tripled from $\$ 4$ per day.

Today, the volume of investments in such sectors as mining, communications, finance, tourism and processing industries is increasing in the southern countries, increasingly growing local markets by providing a large number of local entrepreneurs, which forms the basis of the middle class. As a result of this scenario, which began in the past decades in other regions (under the western powers), structural changes in the economies of the host country of Western economies emerged and responded to the pressure caused by the inflow of investment in the domestic industry by technical and technological modernization. However, the experience shows that this process that technical and technological modernization of production is difficult in countries with poor technological capacities and infrastructure.

What is the solution to the technical and technological modernization of production in our country? Observations show that the reforms being implemented in the country require not only the modernization of technical and technological processes used in the enterprises, but also an innovative approach to management.

According to the State Statistics Committee of Uzbekistan, all enterprises and organizations of our country are currently producing innovative products, products and services with their own capacities.

Picture 1.

${ }^{3}$ Address of the President of the Republic of Uzbekistan ShavkatMirziyoev to Supreme Assembly.http://uza.uz/oz/documents/zbekiston-respublikasi-prezidenti-shavkat-mirziyeevning-oliy-22-12-2017 ${ }^{4}$ http://2018.strategy.uz/ 
Enterprises and organizations of our country are currently producing innovative products, products and services with their own capacities (20102016years) ${ }^{5}$.

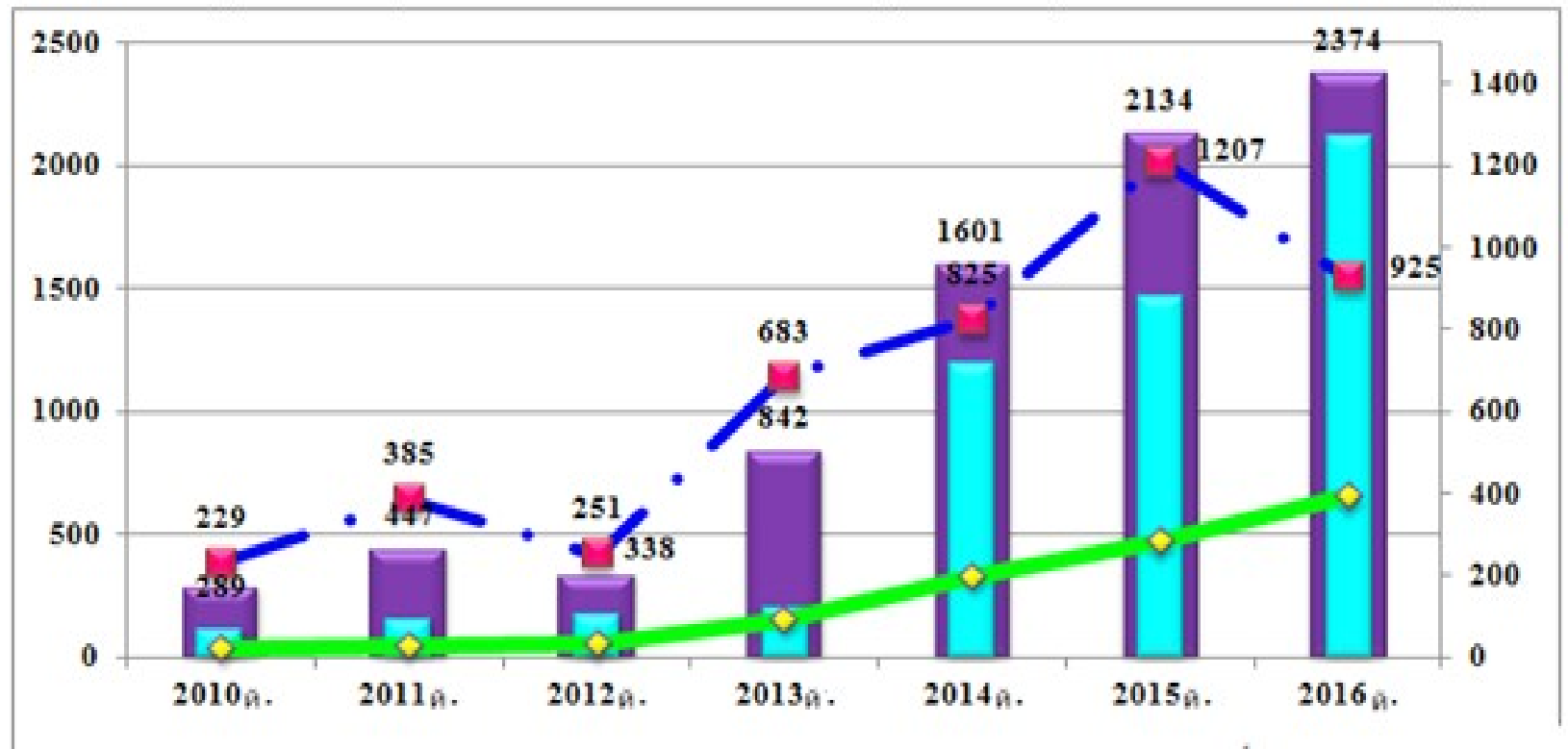

\begin{tabular}{l|l}
\hline & $\begin{array}{l}\text { total innovative products, jobs, services, } \\
\text { enterprises; }\end{array}$ \\
enterprises that have acquired over the last 2 years; \\
first-time acquired enterprises in the reporting year;
\end{tabular}

The number of enterprises and organizations producing innovative products, works, services have increased 8 times from 2010 to 2016, from 289 to 2374.For the first time the number of enterprises, which have mastered the production of innovative products, works and services, has increased by 696 .

Picture 2.

Dynamics of innovation products, works, services volume and expenditure $(2010-2016)^{6}$ 


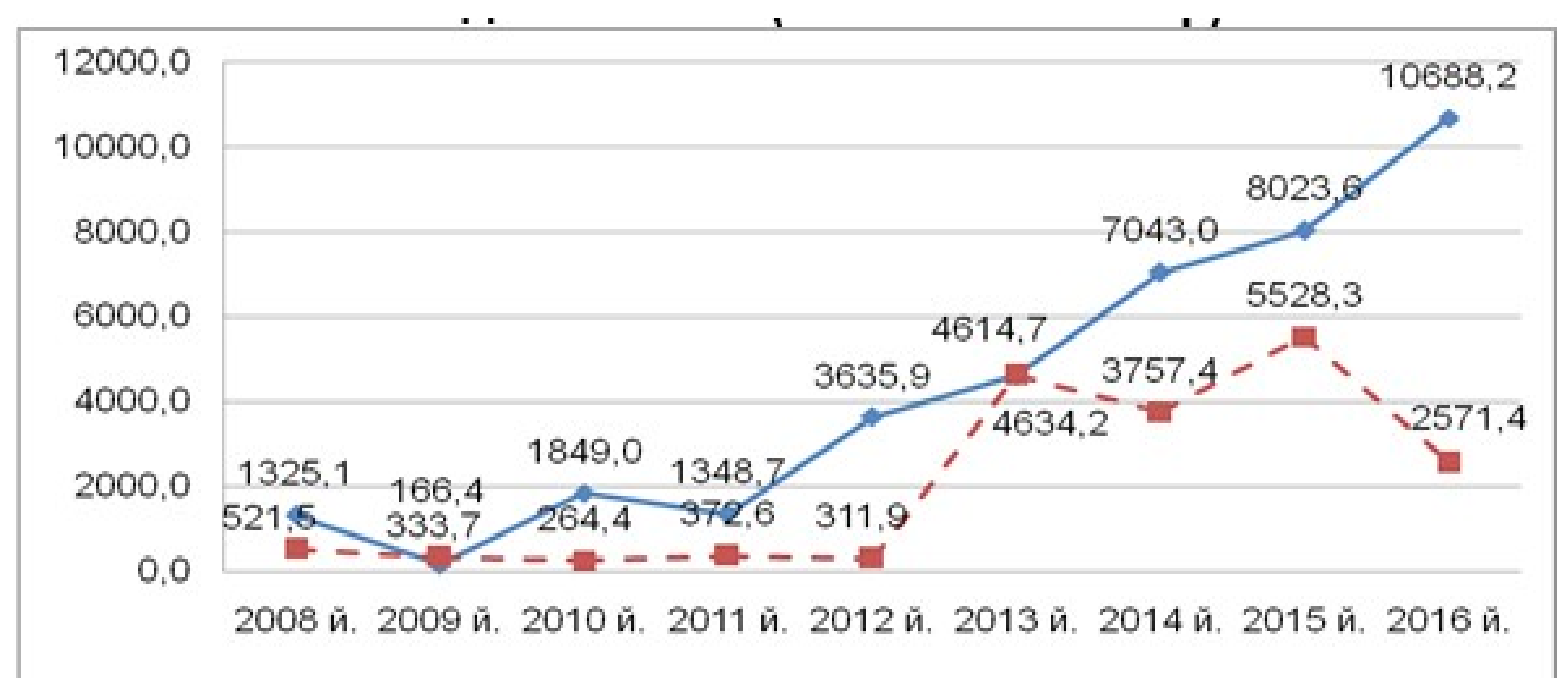

\begin{tabular}{l|l}
$\longrightarrow$ & Innovation goods, services and products, in billion sums; \\
- Innovation costs, in billion sums;
\end{tabular}

Innovative products, works and services will be increased by 2016 to 10688.2 billion sums. This figure is 1.3 times more than in 2015, a 8-fold increase from 2008.Innovative costs increased 5 times in comparison with 2008, down 53\% compared to 2015.

Number of innovations (2016) ${ }^{7}$

\begin{tabular}{|c|c|c|c|c|c|c|}
\hline & $\begin{array}{c}\text { Tota } \\
1\end{array}$ & $\begin{array}{c}\text { by its } \\
\text { own } \\
\text { powe } \\
\text { r }\end{array}$ & $\begin{array}{c}\text { collaboratin } \\
\mathrm{g} \text { with other } \\
\text { organization } \\
\mathrm{s}\end{array}$ & $\begin{array}{l}\text { collaboratin } \\
\text { g with } \\
\text { scientific } \\
\text { research } \\
\text { institutes }\end{array}$ & $\begin{array}{l}\text { collaboratin } \\
\text { g with } \\
\text { higher } \\
\text { educational } \\
\text { institutions }\end{array}$ & $\begin{array}{c}\text { By other } \\
\text { organization } \\
\text { s }\end{array}$ \\
\hline $\begin{array}{l}\text { Technologic } \\
\text { innovations }\end{array}$ & 1816 & 1523 & 117 & 41 & 5 & 176 \\
\hline From them: & & & & & & \\
\hline $\begin{array}{l}\text { Innovations } \\
\text { by products }\end{array}$ & 1118 & 973 & 73 & 15 & 4 & 72 \\
\hline $\begin{array}{l}\text { Innovations } \\
\text { by processes }\end{array}$ & 698 & 550 & 44 & 26 & 1 & 104 \\
\hline $\begin{array}{l}\text { Innovations } \\
\text { by marketing }\end{array}$ & 51 & 39 & - & - & - & 12 \\
\hline $\begin{array}{l}\text { Organizationa } \\
1 \text { innovations }\end{array}$ & 39 & 29 & - & - & - & 10 \\
\hline
\end{tabular}

${ }^{7}$ Thatsource 
In 2016, 893 enterprises and organizations introduced 1816 types of technological innovations. Of the technological innovations, 44\% (799) belong to small enterprises and microfirms. This, in turn, indicates the importance of small business and private entrepreneurship in expanding the middle class in Uzbekistan. Because small business and private entrepreneurship are the cornerstone of this class.

The adoption of measures aimed at the development of small business and private entrepreneurship has enabled us to expand the ranks of the middle class and to increase the incomes of the population.

One of the key points outlined by President Shavkat Mirziyoyev is the following: "During the year we have been in the focus of our attention in creating the most important jobs throughout the year. More than 336,000 new jobs were created in 2017 due to construction of new industrial enterprises, commissioning of small businesses and private entrepreneurship"».

According to the State Statistics Committee of Uzbekistan, the number of people employed in small business and private entrepreneurship in 2000 was about 4.5 million in 2000, while in 2010 this figure was 8.6 million, and in 2016 it was 10.4 million, the number of those employed in this sphere increased by 5.9 million or 2.3 times in comparison with 2000.In 2016, 79.0\% (8.2 million) employed in the sphere of small business and private entrepreneurship, and $21.0 \%$ (2.2 million) were employed in small enterprises and microfirms.

The share of those employed in the small business and private entrepreneurship sector in total employment in 2000 was $49,7 \%, 64,8 \%$ in 2005 , $74,3 \%$ in $2010,78,2 \%$ in 2016 , compared to 2000 , increased by 28.4 percent. In 2016 , the share of employed in small business and private entrepreneurship in the total number of employed in the economy was $78.2 \%$.Of those, $61.9 \%$ were engaged in individual entrepreneurship, $16.3 \%$ were small enterprises and microfirms.

As a result of the adoption of business environment reform measures, the full support and further stimulation of the development of small business and private entrepreneurship, its share in GDP increased from $31.0 \%$ in 2000 to $56.9 \%$ in 2016.

As of January 1, 2017, 61220 small business entities $(28.1 \%$ of the total number of businesses) were engaged in trade, $42862(19.6 \%)$ in industry, 21796 $(10.0 \%)$ in construction, 18051 ( 8,3 per cent) in agriculture, forestry and fishing, 15355 (7,0 percent) in services of living and nutrition, 10639 (4,9 percent) in cargo transportation and storage and 48,247 (22,1 percent) in other sectors functioning 9 .

\footnotetext{
${ }^{8}$ Address of the President of the Republic of Uzbekistan Shavkat Mirziyoev to Supreme Assembly. http://uza.uz/oz/ documents/zbekiston-respublikasi-prezidenti-shavkat-mirziyeevning-oliy-22-12-2017

${ }^{9}$ https://stat.uz/uz/432-analiticheskie-materialy-uz/2031-o-zbekiston-respublikasida-kichik-biznes-va-xususiytadbirkorlikning-rivojlanishi
} 
In our opinion, as a result of the advanced development and expansion of the middle class in the conditions of the modernization of the economy of the country, the following tasks will be addressed:

- social stability is ensured in society;

- the attitude of the population to the events taking place in society changes;

- The tax base is replenished and domestic investment will be increased;

- Socio-economic and socio-cultural behavior of the population will change.

In general, this will help the people of Uzbekistan to increase their productivity and rationality in their workplace, and consequently, to a steady increase in living standards.

\section{References:}

1. The Address of the President of the Republic of Uzbekistan Shavkat Mirziyoev to Supreme Assembly. http://uza.uz/oz/documents/zbekistonrespublikasi-prezidenti-shavkat-mirziyoevning-oliy-22-12-2017

2. http://lex.uz/Pages/GetPage.aspx?lact id $=3431440$

3. http://2018.strategy.uz/

4. Report on Human Development in the Russian Federation for 2015 / ed. L. M. Grigoriev and S. N. Bobylev. -M .: Analytical Center under the Government of the Russian Federation, 2015. C. 7.

5. https://stat.uz/uz/432-analiticheskie-materialy-uz/2038-innovatsion-faoliyat

6. https://stat.uz/uz/432-analiticheskie-materialy-uz/2031-o-zbekistonrespublikasida-kichik-biznes-va-xususiy-tadbirkorlikning-rivojlanishi 